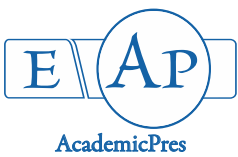

Ojo FM et al. (2021)

Notulae Scientia Biologicae

Volume 13, Issue 4, Article number 11031

DOI: $10.15835 / \mathrm{nsb} 13411031$

Research Article

\title{
Foliar anatomical studies of Andropogon gayanus - Andropogon tectorum complex in Southwestern Nigeria
}

\author{
Funmilola M. OJO ${ }^{1 *}$, Chinyere C. NWOKEOCHA², Julius O. FALUYI ${ }^{3}$ \\ ${ }^{I}$ Olusegun Agagu University of Science and Technology, Department of Biological Sciences (Botany Programme), Okitipupa, \\ Ondo State, Nigeria; olufunmilola_07@yahoo.co.uk (*corresponding author) \\ 2Obafemi Awolowo University, Natural History Museum, Ile-Ife, Osun State, Nigeria; chyabey27@yahoo.com \\ ${ }^{3}$ Obafemi Awolowo University, Department of Botany, Ile-Ife, Osun State, Nigeria; jfaluyi@gmail.com
}

\begin{abstract}
Foliar epidermal studies were carried out on accessions of Andropogon gayanus-Andropogon tectorum complex collected in Southwestern Nigeria with a view to providing additional characters of the two species of Andropogon to enhance the understanding of the taxonomic relationship between the two species. The epidermal preparation of the adaxial and abaxial surfaces of the leaf blade was made from the median part of well-matured leaf samples by the scrapping method. The analysis of both qualitative and quantitative characters revealed that study revealed that the costal zones of both adaxial and abaxial surfaces of all accessions studied showed similar features with little or no variation in their expression; epidermal cells are mostly rectangular with wavy walls, and the stomata encountered are paracytic. There was a unique occurrence of cluster of cells at the base of the macro hairs present in $A$. gayanus which is a diagnostic feature for its accessions collected. Kiwani, an unidentified polyploid accession, has the highest number of bands, the stomata are bigger, which is consistent with gigas effect occasioned by its polyploidy status. Glandular trichomes were present in both diploid and tetraploid of $A$. tectorum, a diagnostic feature for the species.
\end{abstract}

Keywords: Andropogon gayanus; Andropogon tectorum; Kiwani; paracytic

\section{Introduction}

The genus Andropogon Linn. is a large genus of the grass family, Poaceae, belonging to the tribe Andropogoneae (Olorode 1984; Hutchinson and Dalziel, 1972). Andropogon is a pantropical genus of grasses of about 29 species almost confined to the tropical and warm temperate regions of the world, frequently forming an important part of the savanna vegetation in the tropics. Andropogon is represented by about 14 species in Nigeria (Lowe, 1989), although Stanfield (1970) had reported nearly 12 species. The genus is composed of annual and perennial species frequently with tall culms, and leaf blades which can be linear to lanceolate or ovate.

The spikelets occur in pairs at each node of the raceme, consisting of a pedicellate and a sessile spikelet. The sessile spikelet is bisexual, and the pedicellate is unisexual male (Hutchinson and Dalziel, 1972). They are articulated in such a way that at maturity, the spikelets, pedicel and internodes all break apart leaving no central

Received: 16 Jul 2021. Received in revised form: 20 Oct 2021. Accepted: 22 Oct 2021. Published online: 02 Nov 2021.

From Volume 13, Issue 1, 2021, Notulae Scientia Biologicae journal uses article numbers in place of the traditional method of continuous pagination through the volume. The journal will continue to appear quarterly, as before, with four annual numbers. 
inflorescence stalk. The sessile spikelet bears a prominent awn flexed at an angle to the vertical axis of the glumes. A distinct colour difference exists between the two arms of the awn (Clayton, 1969; Stanfield, 1970).

Andropogon gayanus Kunth is a tall, tufted perennial grass that grows taller than $3 \mathrm{~m}$. It has various tillers and abundant foliage, especially during the rainy season (Chlleda and Crowder, 1982). It forms a significant part of the vegetation of many savanna areas throughout Africa south of the Sahara, including South Africa. It is a polymorphic species. In Nigeria, four main varieties were recognized (Clayton, 1962). These are: var. gayanus (var. genuinus) Hack, var. bisquamulatus (Hochst) Hack var. squamulatus (Hochst) Stapf and var. tridentatus. Bowden (1963) considered var. tridentatus as split from var. bisquamulatus thus recognizing only three varieties. A. gayanus is widespread and abundant in the Northern and Southern Guinea Savanna and the drier areas of the derived savanna, whereas $A$. tectorum occupies vast areas in the derived savanna, preferring moderate shade (Stanfield, 1970). However, certain areas in the derived savanna support the growth of both species equally well (Okoli and Olorode, 1983). Andropogon gayanus is propagated by seeds, which are broadcasted or planted in rows and vegetatively by splitting the tufts. It is relatively free of major pests and diseases and is resistant to grazing and burning. These make it a useful grass for supporting a large number of ruminant animals in Northern Nigeria. It is also one of the high-yielding grasses in West Africa (Bogdan, 1977; Pagot, 1993). The economic importance of Andropogon gayanus for livestock grazing is that it is very palatable when young and serves as basic material for woven houses. Andropogon gayanus is a highly-productive grass, which increases fuel loads, produces intense, late dry season fires which seriously damage native woody species; it is also useful as forage in permanent pastures grazed by ruminants. The stems are used for thatching and, when flattened, for weaving coarse grass mats as well as sometimes being planted for erosion control and soil restoration.

Taxonomists were limited in the early 19th century to using the characteristics of reproductive organs, as floral characters were considered to be the most useful markers of taxonomic affinities (Nwokeocha, 1996). The leaf is the most commonly used in plant taxonomy, of all the non-reproductive organs. Stace $(1965,1984)$ and Srivastava (1978) described the epidermis of the leaf as the second most important character for solving taxonomic problems after cytology.

Following works by Metcalfe and Chalk (1950), which serve as standard guides on Plant Anatomy, the use of vegetative anatomical characters became a regular taxonomic practice. Since then, the enormous importance of the leaf epidermis and vegetative anatomy in grass systematics has been demonstrated successfully by many workers, among whom are Tateoka, Inoue and Kwano (1959), Prat (1960), Srivastava (1978); Renvoize (1982, 1987), Hattersley (1984); Plamer and Gerbeth Jones (1986, 1988). Ogundipe and Olatunji $(1989,1991)$.

Carlquist (1961) emphasized the contribution of stomatal size variations to the delimitation of species within a genus. Illoh (1995) worked on the foliar anatomy of four species of Celosia occurring in Southwestern Nigeria. He reported that the leaf provides a variety of anatomical features which may be of taxonomic utility.

Metcalfe (1954) noted that certain characters of the epidermis, such as the shape of the subsidiary cells of the stomata, micro hairs and silica cells, are essential systematically. Metcalfe (1960) identified four types of subsidiary cells, parallel sided, low-dome, triangular and high-dome, in the stomata of matured grasses. Folorunso and Olaniyan (2009) identified prominent features that are more conspicuous in A. gayanus than in $A$. tectorum, which may be adaptive and endemic in Savanna species. Such characters are the thick wall of cells, the form of stomata, shape and size of papillae. Their findings showed that there are many anatomical variations between these two species of Andropogon they studied. However, some of the characters were present in all of them and may be typical of this genus of the family. 


\section{Materials and Methods}

\section{Germplasm survey, collection and field culture}

Field trips for plant collections covered agro-ecological zones of the following states: Osun, Ondo, Ogun, Oyo and Ekiti as shown in Figure 1. Whole plants of Andropogon gayanus and Andropogon tectorum were collected from different locations in Southwest, Nigeria. Accession numbers were given to the specimens. Seeds were also collected for planting and preservation. Garden populations were raised from the vegetative parts of some accessions and they were also maintained in the Botanical Garden of the Obafemi Awolowo University, Ile- Ife, Osun State and morphological attributes of each species were recorded (Plates 1-2). The accessions were nurtured to maturity and used for this study. Table 1 shows the locations, coordinates, descriptions of the site and collectors of the accessions.

\section{Foliar epidermal studies}

Foliar epidermal features were studied and documented using the scraping method as described by some workers like Cutler (1978); Ogundipe and Olatunji (1991) and modified by Nwokeocha (1996). The epidermal preparation of the adaxial and abaxial surfaces of the leaf blade was made for all accessions of Andropogon tectorum and Andropogon gayanus collected. The median part of well matured leaf samples was scraped using smooth sandpaper on a glass slide after which the peels were decolourized in $5 \%$ sodium hypochlorite (domestic bleach) for 30-60 minutes. The cleared epidermal peels were preserved in 50\% ethanol, stained in Safranin $\mathrm{O}$ and counter-stained in Alcian blue to enhance contrast. All the preparations were mounted in $25 \%$ glycerol. Both adaxial and abaxial surfaces of the leaves were studied. Quantitative and qualitative data were made recorded on characters such as long cells, short cells, stomata, subsidiary cells, trichomes, prickle hair and papillae. All microscopic measurements were taken with an ocular micrometer inserted in the eyepiece of the microscope and converted to standard units. Illustrations of the foliar epidermal features were photographed at X10 and X20 objectives under BK Series (Phase Contrast Microscope (PW-BK 5000T) equipped with a DCM 5105 Megapixel Camera.

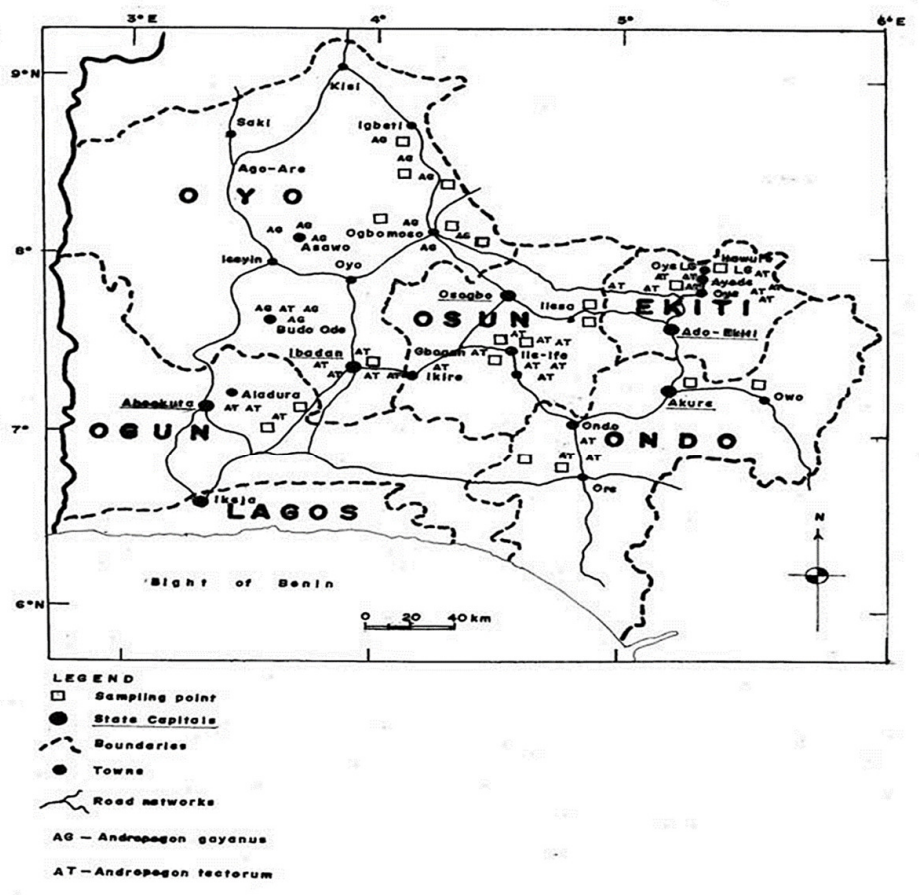

Figure 1. Map showing collection sites 
Table 1. Accessions of Andropogon gayanus (Kunth) - Andropogon tectorum(Schum \& Thonns) studied and their sources

\begin{tabular}{|c|c|c|c|c|}
\hline $\mathrm{ACCN}$ & Locations & Coordinates & Descriptions of site & Collectors \\
\hline AG 1 & Asawo, Oyo State & 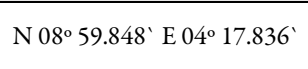 & $\begin{array}{c}\text { Ruderal location, regular regrowth } \\
\text { forest }\end{array}$ & $\begin{array}{c}\text { Ojo, Faluyi, Azeez and } \\
\text { Abraham }\end{array}$ \\
\hline AG 2 & Budo-Ode, Oyo State & $\mathrm{N} 08^{\circ} 20.420^{\prime}$ E $04^{\circ} 14.039^{\prime}$ & Derived Savanna & $"$ \\
\hline AG 3 & $\begin{array}{c}\text { Between Ogbomosho and } \\
\text { Oko, Oyo State }\end{array}$ & $\mathrm{N} 08^{\circ} 59.854^{\prime}$ E $04^{\circ} 17.835^{\prime}$ & $\begin{array}{c}\text { Ruderal location, regular regrowth } \\
\text { forest }\end{array}$ & ", \\
\hline AG 4 & Igbeti 1 , Oyo State & $\mathrm{N} 08^{\circ} 24.722^{\prime} \mathrm{E} 04^{\circ} 15.467^{\prime}$ & $\begin{array}{c}\text { Dry water course, populated by a heavy } \\
\text { mat of grasses and sedges; chimeric } \\
\text { lawn }\end{array}$ & $"$ \\
\hline AG 5 & Igbeti 2, Oyo State & $\mathrm{N} 08^{0} 24.723^{\prime}$ E $04^{0} 15.467^{\prime}$ & $\begin{array}{c}\text { Dry watercourse, populated by a heavy } \\
\text { mat of grasses and sedges; chimeric } \\
\text { lawn }\end{array}$ & $"$ \\
\hline AG 6 & Ogbomosho, Oyo State & $\mathrm{N} 08^{\circ} 34.794^{\prime}$ E $04^{\circ} 14.669^{\prime}$ & $\begin{array}{l}\text { Regular regrowth forest with the } \\
\text { presence of multiple grass species }\end{array}$ & $"$ \\
\hline AT 1 & $\begin{array}{l}\text { OAUTHC Road, Osun } \\
\text { State }\end{array}$ & $\mathrm{N} 07^{\circ} 30.870^{\prime} \mathrm{E} 04^{\circ} 33.065^{\prime}$ & $\begin{array}{c}\text { Ruderal location with dwarf } \\
\text { morphotypes propagating from } \\
\text { crevices }\end{array}$ & $\begin{array}{l}\text { Ojo, Faluyi and } \\
\text { Nwokeocha }\end{array}$ \\
\hline AT 2 & $\begin{array}{c}\text { O.A.U. Religious Centre, } \\
\text { Osun State }\end{array}$ & $\mathrm{N} 07^{\circ} 30.703^{\prime}$ E $04^{\circ} 33.065^{\prime}$ & $\begin{array}{c}\text { Ruderal on lateritic soil in the company } \\
\text { of other grasses, Asteraceae }\end{array}$ & $"$ \\
\hline AT 3 & $\begin{array}{l}\text { O.A.U. International School, } \\
\text { Osun State }\end{array}$ & 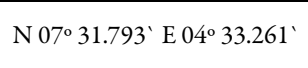 & $\begin{array}{l}\text { Expanse of lateritic soil with close } \\
\text { communities of Andropogon tectorum }\end{array}$ & " \\
\hline AT 4 & Ife-Ibadan Road, Osun State & $\mathrm{N} 07^{\circ} 22.774^{\prime}$ E $04^{\circ} 01.497^{\prime}$ & $\begin{array}{l}\text { At the fringe of road divider, } \\
\text { surrounded by other grasses }\end{array}$ & Ojo and Faluyi \\
\hline AT 5 & $\begin{array}{c}\text { Ondo road, Along Ore, } \\
\text { Ondo State } \\
\end{array}$ & $\mathrm{N} 07^{\circ} 49.468^{\prime}$ E $04^{\circ} 52.444^{\prime}$ & Ruderal on lateritic soil & Ojo \\
\hline AT 6 & Aladura, Ogun State & $\mathrm{N} 07^{\circ} 30.068^{\prime}$ E $04^{\circ} 27.885^{\prime}$ & Ruderal on lateritic soil & Ojo and Faluyi \\
\hline AT 7 & Omu-Ayede road, Ekiti State & $\mathrm{N} 07^{\circ} 54.374^{\prime} \mathrm{E} 05^{\circ} 20.167^{\prime}$ & $\begin{array}{l}\text { Ruderal location with a cluster of } \\
\text { Panicum maximum and stands of } \\
\text { Chromolana odorata }\end{array}$ & $\begin{array}{l}\text { Faluyi, Matthew and } \\
\text { Abraham }\end{array}$ \\
\hline AT 8 & Itaji-Oye Road, Ekiti State & $\mathrm{N} 07^{\circ} 50.833^{\prime} \mathrm{E} 05^{\circ} 20.661^{\prime}$ & $\begin{array}{c}\text { Ruderal location under a tree of Parkia } \\
\text { biglobosa and Alchornea laxiflora }\end{array}$ & $\begin{array}{c}\text { Faluyi, Matthew and } \\
\text { Abraham }\end{array}$ \\
\hline AT 9 & Ayede-Oye Road, Ekiti State & $\mathrm{N} 07^{\circ} 50.438^{\prime} \mathrm{E} 05^{\circ} 20.733^{\prime}$ & $\begin{array}{c}\text { Solitary plant, leaves are broad and } \\
\text { usually short; in mesic location }\end{array}$ & $"$ \\
\hline AT 10 & Erinmo Road, Ekiti State & $\mathrm{N} 07^{\circ} 38.203^{\prime} \mathrm{E} 04^{\circ} 51.755^{\prime}$ & $\begin{array}{l}\text { Ruderal location on lateritic soil in the } \\
\text { company of other grasses, Asteraceae }\end{array}$ & $"$ \\
\hline
\end{tabular}

ACCN - Accession, AG- Andropogon gayanus, AT- Andropogon tectorum

\section{Results}

\section{Foliar epidermal studies}

Andropogon gayanus (Plates 3 and 4)

Abaxial surface (Plates $3 \mathrm{~A}-\mathrm{D}$ )

Anticlinal walls are straight and slightly wavy. Plate 3B.

Long cells: rectangular, slightly elongated many times longer than broad; breadth more or less uniform; cell wall straight and prominently slightly wavy; end walls mostly perpendicular; 4-5 rowed between the costal zones, the cell wall is thick and straight, numerous papillae are present, small and of uniform sizes, present inbetween the stomata (Plate 3B). Cork cells (single, unpaired) are present (Plate 3C).

Short cells: solitary and more or less of equal sizes, in pairs or groups, in continuous rows along costal zones; mostly 1 row per costal region but occasionally up to 2 or 3 , occurring on a straight line in between rows of stomata, found in between prickle hair, as shown in Plate 3C.

Stomata: Fairly frequent to abundant; paracytic; subsidiary cells triangular to low-dome shape; end walls mostly perpendicular; 1-2 bands of stomata per intercostal zone (Plate 3C and D).

Interstomatal cells: Slightly rectangular; length and width more or less uniform; transverse and walls concave; anticlinal cell wall wavy. (Plate $3 \mathrm{C}$ and D). 
Prickle hair: Frequent; oblique, big round base with a blunt end, in rows between the short cells just after the costal region. (Plate 3C).

Microhairs: Very frequent, longer than in the Andropogon tectorum, each hair has a unique base surrounded by a cluster of cells that provides a bigger platform for the hair to sit; modified in shape; apex sharp to blunt; tapers up; thick cell wall as shown in Plate 3A. No glandular trichome was seen.

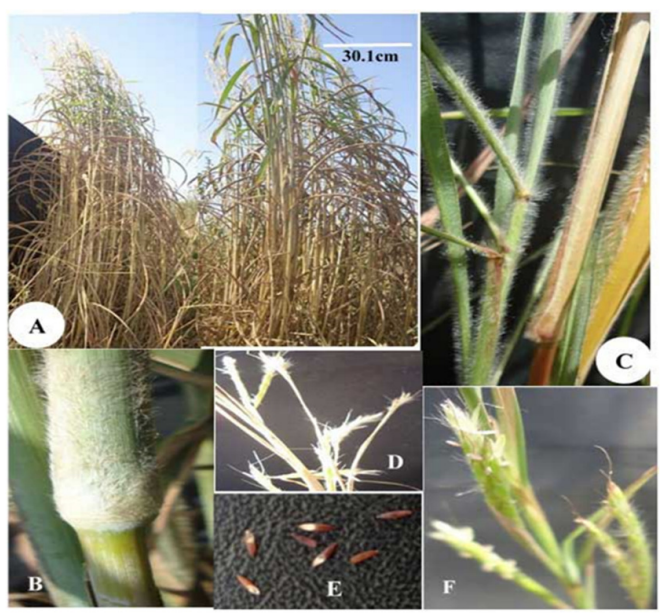

Plate 1. Morphological features of Andropogon gayanus

A-Plant form and adaptation; B-Internode; C-Hairy leaf sheath; D-Raceme pairs; E-Seeds; F-Spikelet

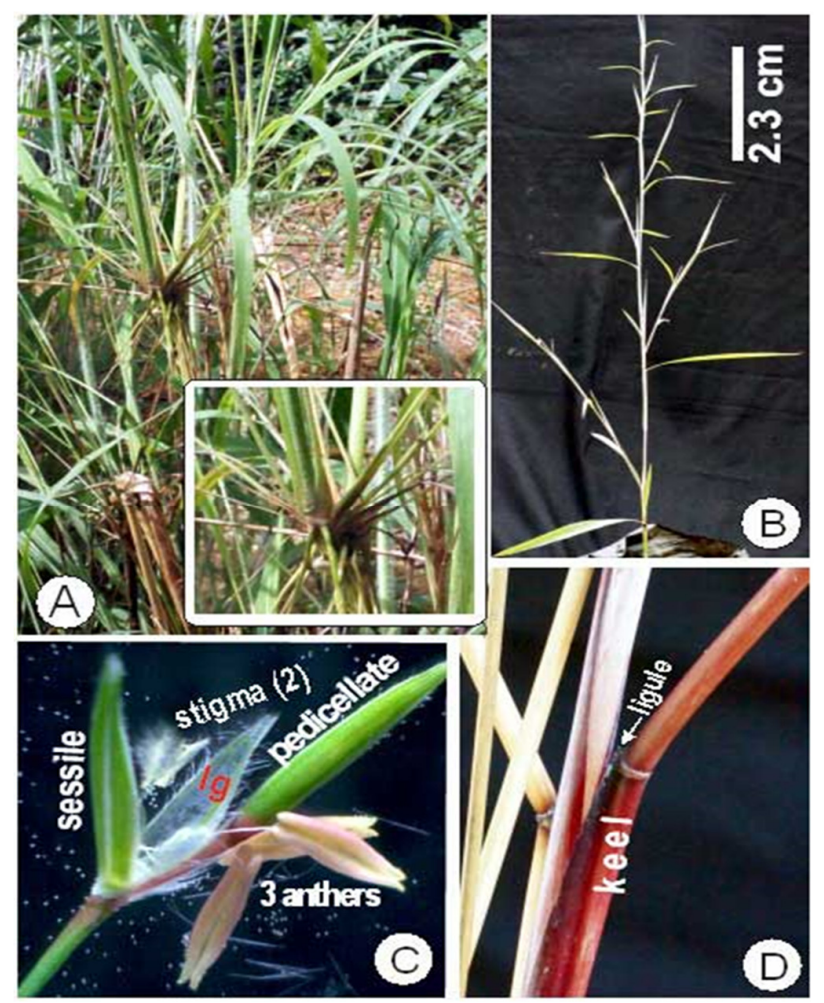

Plate 2. Morphological features of Andropogon tectorum

A-Plant form and adaptation (Insect- Rooting at the node); B-Flowering Scape; C-Spikelet; D-The leaf showing sheath, keel and ligule; $\lg$ - lower glume 

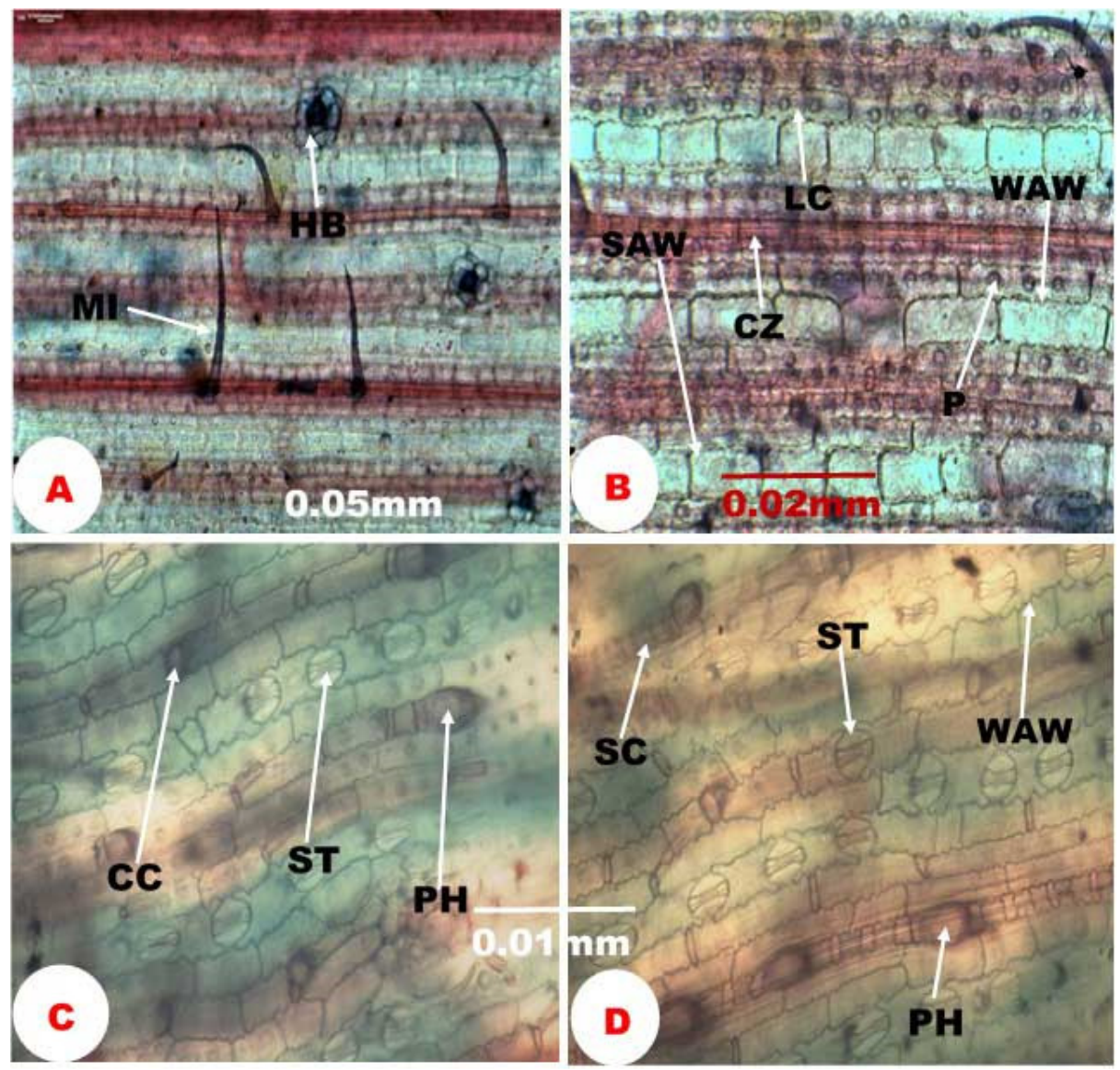

Plate 3A- D. Epidermal features of the abaxial surfaces of $A$. gayanus accessions

CC- Cork cell, CZ- Costal zone, HB- Hair Base, LC- Long cell, MI- Microhair, P - Papillae, PH- Prickle Hair, SAW

- Straight Anticlinal Wall, SC-Short cell, ST - Stomata, WAW - Wavy anticlinal wall

\section{Adaxial surface (Plate 4A-D)}

Anticlinal walls are straight and slightly wavy (Plate $4 \mathrm{~B}$ and $\mathrm{C}$ ).

Long cells: rectangular, conspicuously elongated (many times longer than broad) with width more or less uniform, cell wall straight, prominently slightly wavy and sometimes straight; end walls mostly perpendicular; 7-9 rowed between the veins, cell wall is thick and straight, papillae present, numerous and uniform in size, as shown in Plate $4 \mathrm{~B}$ and C.

Short cells: Infrequent; in continuous rows along veins, solitary and more or less of equal sizes but occasionally paired, mostly occurring on a straight line close to base of hair, $2-3$ rows as shown in Plate 4C. No cork cell encountered.

Stomata: Paracytic stomata type present, sparse than on the abaxial surface, subsidiary cells triangular to low-dome 2-3 rows, end walls mostly perpendicular (Plate 4A).

Interstomatal cells: Rectangular; 2 - 5 times longer than broad; transverse and walls concave; anticlinal cell wall slightly wavy (Plate 4).

Prickle hair: Very sparse; elongated; base small, raised, apex sharply pointed (Plate 4B).

Microhairs: More frequent, long, each hair has a base surrounded by a cluster of cells that provide a bigger platform for the hair to sit; modified in shape; apex sharp to blunt; taper up; thick cell wall as shown in Plate $4 \mathrm{~A}$ and $\mathrm{B}$. No glandular trichome seen. 

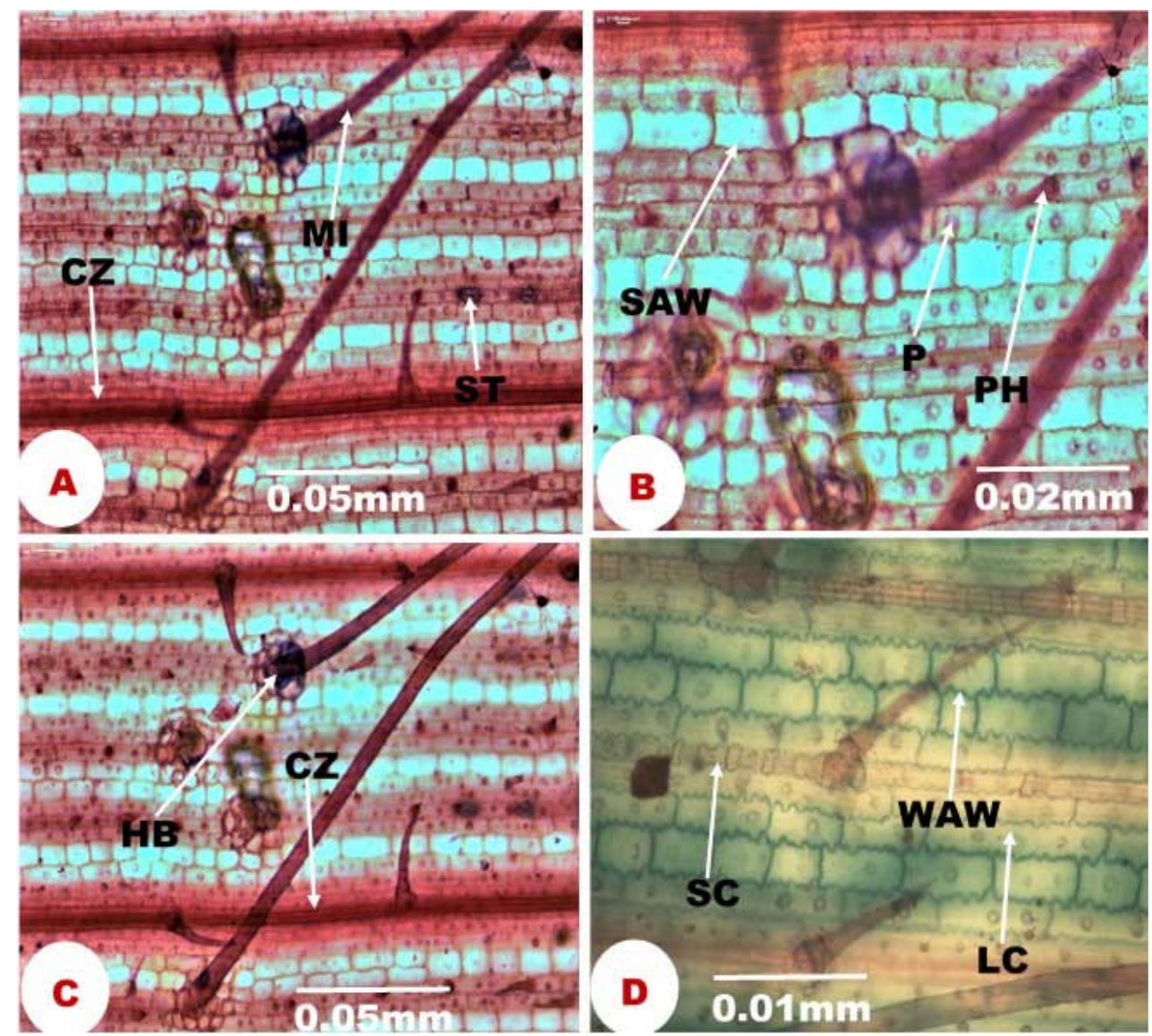

Plate 4A - D. Epidermal features of the Adaxial Surfaces of A. gayanus accessions

CZ- Costal zone, HB- Hair Base, LC- Long cell, MI- Microhair, P - Papillae, PH- Prickle Hair, SAW - Straight Anticlinal Wall, SC-Short cell, ST - Stomata, WAW - Wavy anticlinal wall

\section{Andropogon tectorum (Plates 5 and 6 )}

Abaxial surface (Plates $5 \mathrm{~A}-\mathrm{E}$ )

Anticlinal wall is wavy, as shown in Plate 5B.

Long cells: rectangular, conspicuously elongated; many times, longer than broad; 2-3 rows between the veins, the cell wall is thin and prominently wavy; end walls perpendicular; papillae present; small and of uniform size (Plate 5B).

Short cell: Abundant, present on both costal and intercostal zone in continuous rows along veins but more frequent on the costal zones in between rows of prickle hairs. All the costal zones are covered with papillae, some of the short cells are paired in the intercostal zone and a row of stomata was present in the middle row of the intercostal zone (Plate 5B).

Stomata: numerous; dome-shaped, paracytic; subsidiary cells triangular to low-dome; 3-4 banded between the costal zones, Cork cells present, unpaired (Plate 5A).

Interstomatal cells: Rectangular; longer than broad; transverse and walls concave; anticlinal cell wall wavy (Plate 5D).

Prickle hair: Frequent; elongated; occurs in rows on costal zones having rows of stomata above and below, they vary in sizes and shapes, some have big round base with a slightly pointed end (Plate 9A) while some have raised round base with apex sharply pointed; acute tip (Plate 5C).

Microhairs: infrequent; long and slender; raised; sharply pointed; the tips are bluntly acute and the apex can be clearly seen; unmodified. Plate 5C. Presence of glandular trichome. 


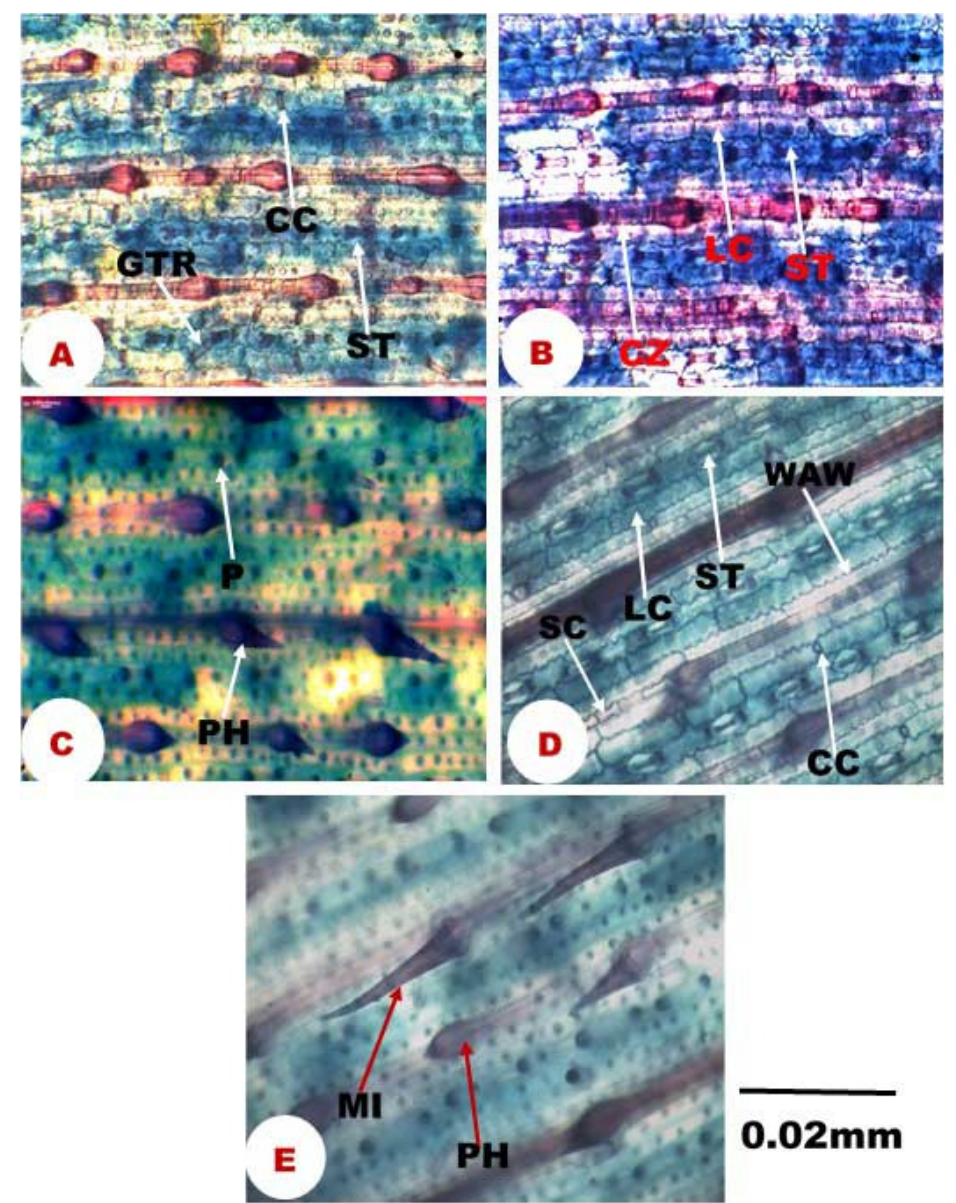

Plate 5A - E. Epidermal features of the abaxial surfaces of $A$. tectorum accessions

A, AT6 showing costal prickles with 3 intercostal zones, glandular trichome and cork cell; B, AT4 showing costal prickles with rows of stomata on intercostal zones; C, AT1 showing costal prickles and papillae; D, AT3 showing 4 costal zones with prickle hairs and 3 intercostal zones; E, AT3 showing microhairs and Prickle hairs. CC- Cork cell, CZ- Costal zone, GTR - Glandular trichome, LC- Long cell, MI- Microhair, P - Papillae, PH- Prickle Hair, SC- Short cell, ST - Stomata, WAW - Wavy anticlinal wall

\section{Adaxial surface (Plates 6A - D)}

The anticlinal wall is wavy as shown in Plate 6C.

Long cells: rectangular, conspicuously elongated (many times longer than broad) 7-8 rowed between the veins, cell wall is thick and wavy, papillae present with uniform size; cork cells in between long cells (Plate 6D).

Short cells: frequent, present over the veins in rows of 2 or more cells, paired, occurred on costal region in between prickle hairs, costal short cells are numerous, intercostal short cells are also present. All the costal zones are covered with medium-sized papillae (Plate 6C), cork cells occurred but rare (Plate 6A and B).

Stomata: they are more abundant here and not restricted to the middle like the on the abaxial surface; paracytic; subsidiary cells triangular to low-dome; 2 banded between the veins.

Interstomatal cells: Polygonal; length and width more or less uniform; transverse and walls concave; anticlinal cell wall wavy.

Prickle hair: Frequent, occurs in rows on costal and intercostal regions, in between short cells (Plate 6B) and in between rows of stomata (Plate 6C).

Microhairs are present in the middle of intercostal zone; the hairs are raised, unmodified; the tips are bluntly acute and the apex can be clearly seen. Glandular trichomes were also found in the intercostal zone. Cork cells present, unpaired. 

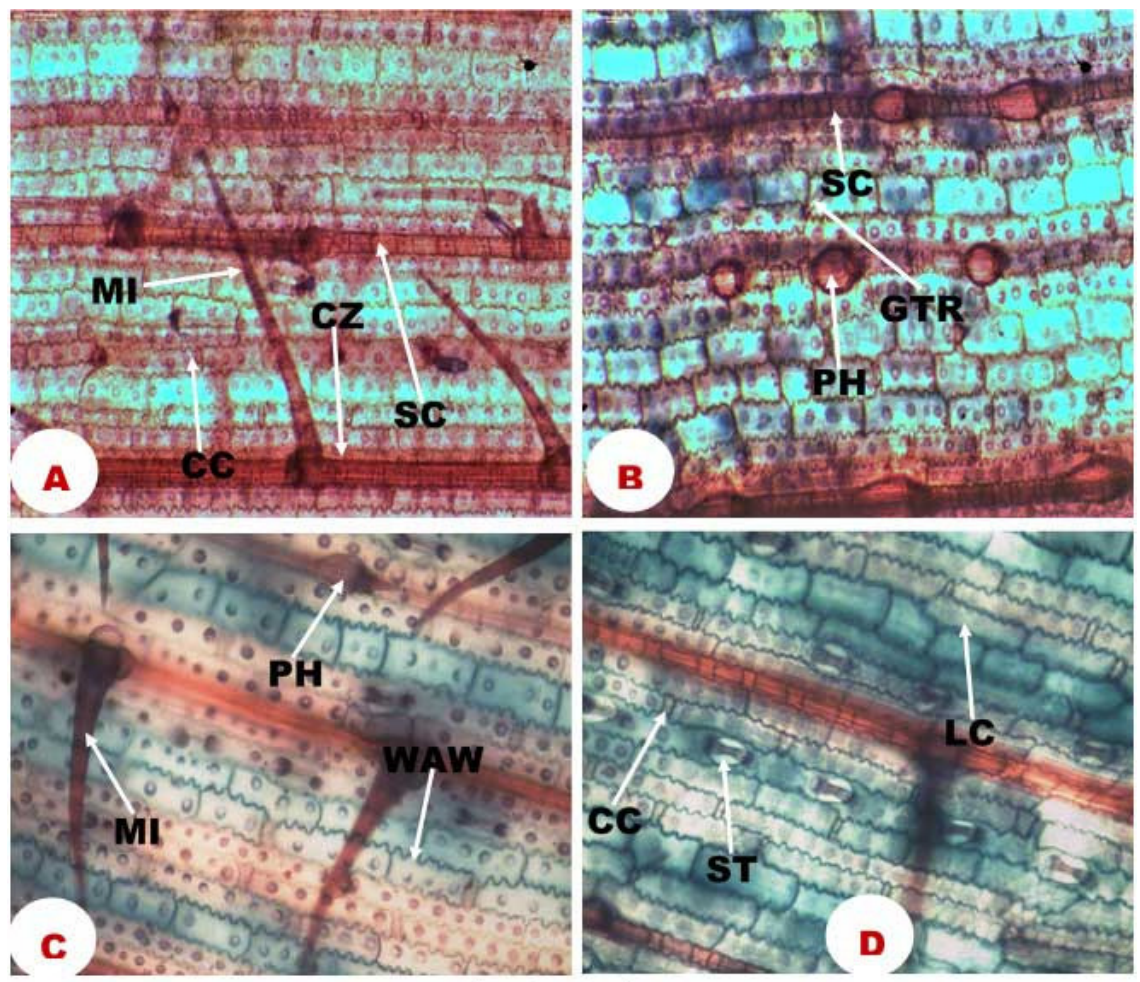

\section{$\overline{0.02 \mathrm{~mm}}$}

Plate 6A - D. Epidermal features of the Adaxial Surfaces of $A$. tectorum accessions

A, AT6 showing 2 costal zones with microhairs on costal zone; B, AT4 showing costal prickles with 2 intercostal zones; C, AT1 showing 2 intercostal zones, costal prickle and microhairs; D, AT3 showing 1 costal zone, 2 intercostal zones, rows of stomata and cork cells. CC- Cork cell, CZ- Costal zone, GTR- Glandular trichome, LC- Long cell, MI-

Microhair, P- Papillae, PH- Prickle Hair, SC-Short cell, ST- Stomata, WAW- Wavy anticlinal wall

\section{$\underline{K I W A N I(\text { Plate } 7 \mathrm{~A}-\mathrm{D})}$}

Abaxial Surface (Plates $7 \mathrm{~A}$ and B)

Long cells: Rectangular, many times longer than broad; cell wall markedly sinuous and wavy; end walls mostly perpendicular.

Short cells: Less frequent; solitary or paired; in continuous rows along the veins in-between prickle hairs. Cork cells in between long cells (Plate 7A and B). All the costal zones are covered with medium-sized papillae as shown in Plate $7 \mathrm{~B}$.

Stomata: Abundant; paracytic; very large subsidiary cells triangular to low-dome, present in rows on the intercostal zone (Plate 7A and B).

Interstomatal cells: Rectangular; $2-5$ times longer than broad; transverse and walls concave; anticlinal cell wall wavy as shown in Plates 7A and B.

Prickle hair: Frequent; base big and round, raised; with slightly pointed end; occurring in rows on the costal zone (Plate $7 \mathrm{~A}$ and $\mathrm{B})$.

Microhairs are present, infrequent, round base, raise, unmodified; long and slender with the apex sharply pointed, as shown in Plate 7B.

\section{Adaxial surface (Plates $7 \mathrm{C}$ and D)}

The anticlinal wall is wavy, as shown in Plate 7C.

Long cells: rectangular, conspicuously elongated (many times longer than broad) 5-8 rows between the veins, cell wall thick and wavy, papillae present with uniform size; very big. 
Short cells: frequent; solitary or paired; in continuous rows along the veins, occurred on costal region in between prickle hairs, costal short cells are numerous, intercostal short cells are also numerous. Cork cells solitary in between cells (Plate 7C and D). All the costal zones are covered with medium sized papillae (Plate $7 \mathrm{C}$ and $\mathrm{D})$.

Stomata: Less frequent; paracytic; subsidiary cells triangular to low-dome, 2 bands between the veins as shown in Plates $7 \mathrm{C}$ and D.

Interstomatal cells: Rectangular; many times, longer than broad; transverse and walls concave; anticlinal cell wall wavy (Plate 7D).

Prickle hair: Less frequent; occurs in rows on costal and intercostal regions; round base; with slightly pointed end (Plates $7 \mathrm{C}$ and $\mathrm{D})$.

Microhairs are present in the middle of intercostal zone. The hairs are raised; long; slender; sharp end as shown in Plate 7C. Glandular trichomes were found in the intercostal zone. Cork cells present, solitary.

Table 2 shows the summary of the Leaf Epidermal characteristics of the accessions studied.

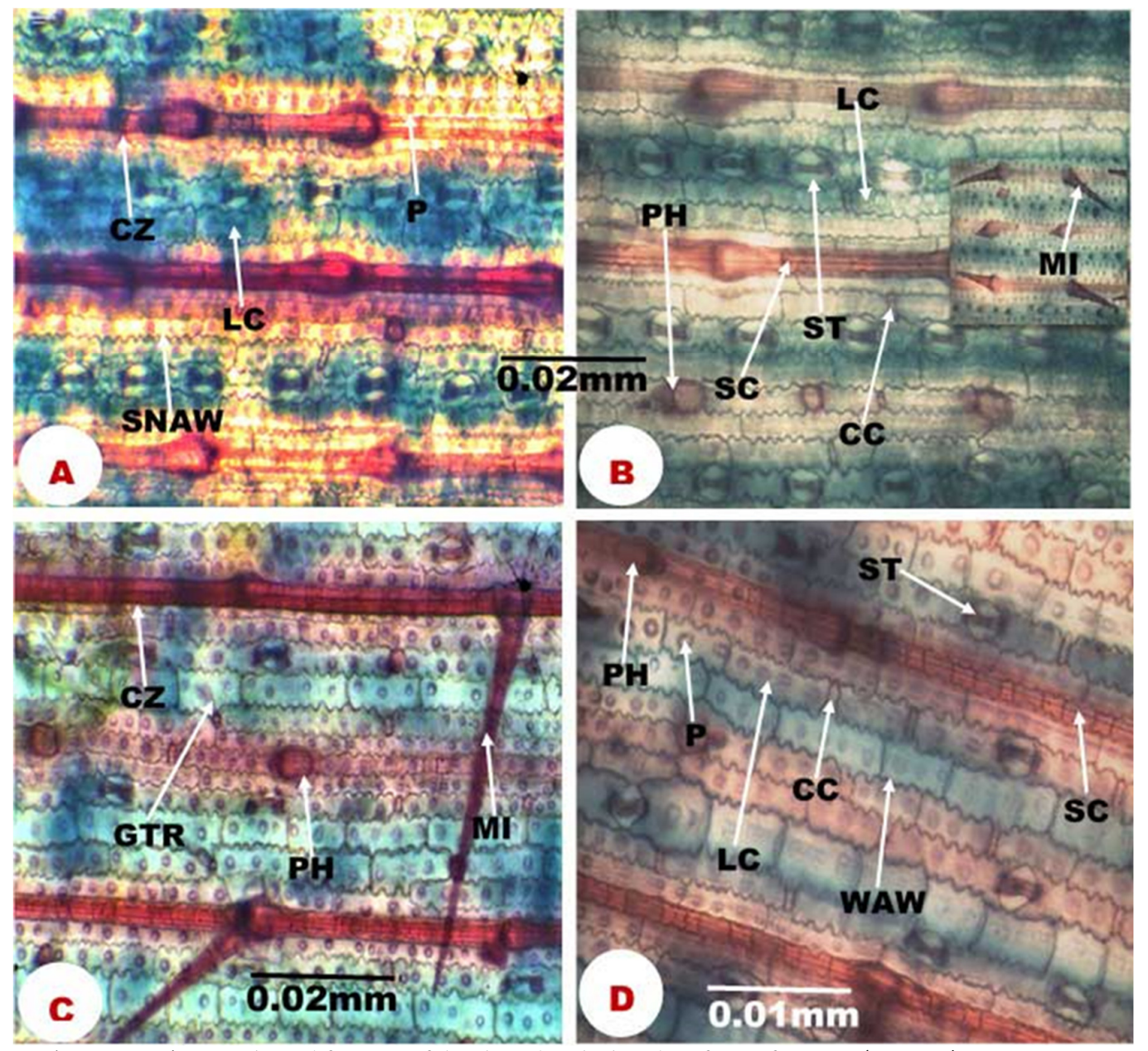

Plate 7A and B. Epidermal features of the abaxial and adaxial surfaces of Kiwani $(2 n=40)$

CC- Cork cell, CZ- Coastal zone, GTR-Glandular Trichome, LC- Long cell, MI- Microhair, P- Papillae, PH- Prickle Hair, SC-Short cell, ST- Stomata, SNAW- Sinuous Anticlinal wall, WAW- Wavy anticlinal wall 
Ojo FM et al. (2021). Not Sci Biol 13(4):11031

Table. Summary of the leaf epidermal characteristics of all the accessions of Andropogon gayanusAndropogon tectorum studied

\begin{tabular}{|c|c|c|c|c|c|c|c|c|c|c|}
\hline Serial No & Accn. & Positions & Cell Shape & Anticlinal wall & Microhairs & Long cells & Short cells & Stomata & Cork cell & $\begin{array}{l}\text { Glandular } \\
\text { Trichome }\end{array}$ \\
\hline \multirow[t]{2}{*}{1} & \multirow{2}{*}{ AG1 } & Abaxial & Rectangular & Straight, slightly wavy & + & + & + & Paracytic & + & - \\
\hline & & Adaxial & $"$ & " & + & + & + & " & + & - \\
\hline \multirow[t]{2}{*}{2} & \multirow{2}{*}{ AG2 } & Abaxial & $"$ & $"$ & + & + & + & 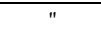 & + & - \\
\hline & & Adaxial & $"$ & $"$ & + & + & + & $"$ & + & - \\
\hline \multirow[t]{2}{*}{3} & \multirow{2}{*}{ AG3 } & Abaxial & $"$ & " & + & + & + & $"$ & + & - \\
\hline & & Adaxial & $"$ & $"$ & + & + & + & $"$ & + & - \\
\hline \multirow[t]{2}{*}{4} & \multirow{2}{*}{ AG4 } & Abaxial & $"$ & $"$ & + & + & + & $"$ & + & - \\
\hline & & Adaxial & $"$ & $"$ & + & + & + & $"$ & + & - \\
\hline \multirow[t]{2}{*}{5} & \multirow{2}{*}{ AG5 } & Abaxial & $"$ & $"$ & + & + & + & $"$ & + & - \\
\hline & & Adaxial & $"$ & 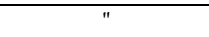 & + & + & + & " & + & - \\
\hline \multirow[t]{2}{*}{6} & \multirow{2}{*}{ AG6 } & Abaxial & $"$ & $"$ & + & + & + & $"$ & + & - \\
\hline & & Adaxial & $"$ & $"$ & + & + & + & $"$ & + & - \\
\hline \multirow[t]{2}{*}{7} & \multirow{2}{*}{ AT1 } & Abaxial & $"$ & Wavy & + & + & + & $"$ & + & + \\
\hline & & Adaxial & $"$ & $"$ & + & + & + & $"$ & + & + \\
\hline \multirow[t]{2}{*}{8} & \multirow{2}{*}{ AT2 } & Abaxial & $"$ & $"$ & + & + & + & $"$ & + & + \\
\hline & & Adaxial & $"$ & $"$ & + & + & + & $"$ & + & + \\
\hline \multirow[t]{2}{*}{9} & \multirow{2}{*}{ AT3 } & Abaxial & $"$ & $"$ & + & + & + & $"$ & + & + \\
\hline & & Adaxial & $"$ & $"$ & + & + & + & $"$ & + & + \\
\hline \multirow[t]{2}{*}{10} & \multirow{2}{*}{ AT4 } & Abaxial & $"$ & $"$ & + & + & + & $"$ & + & + \\
\hline & & Adaxial & $"$ & $"$ & + & + & + & $"$ & + & + \\
\hline \multirow[t]{2}{*}{11} & \multirow{2}{*}{ AT5 } & Abaxial & $"$ & $"$ & + & + & + & $"$ & + & + \\
\hline & & Adaxial & $"$ & $"$ & + & + & + & $"$ & + & + \\
\hline \multirow[t]{2}{*}{12} & \multirow{2}{*}{ AT6 } & Abaxial & $"$ & $"$ & + & + & + & $"$ & + & + \\
\hline & & Adaxial & $"$ & $"$ & + & + & + & $"$ & + & + \\
\hline \multirow[t]{2}{*}{13} & \multirow{2}{*}{ AT7 } & Abaxial & $"$ & $"$ & + & + & + & $"$ & + & + \\
\hline & & Adaxial & $"$ & $"$ & + & + & + & $"$ & + & + \\
\hline \multirow[t]{2}{*}{14} & А Те & Abaxial & $"$ & " & + & + & + & $"$ & + & + \\
\hline & A18 & Adaxial & $"$ & $"$ & + & + & + & $"$ & + & + \\
\hline 15 & ATQ & Abaxial & $"$ & $"$ & + & + & + & $"$ & + & + \\
\hline & A19 & Adaxial & $"$ & " & + & + & + & $"$ & + & + \\
\hline 16 & AT10 & Abaxial & $"$ & $\begin{array}{c}\text { Sinuous and wavy } \\
\text { anticlinal wall }\end{array}$ & + & + & + & $"$ & + & + \\
\hline & & Adaxial & $"$ & " & + & + & + & $"$ & + & + \\
\hline
\end{tabular}


Table 3. Mean of some leaf epidermal characters on the adaxial surfaces of all the accessions studied with Duncan multiple range test values

\begin{tabular}{|c|c|c|c|c|c|c|c|c|c|}
\hline $\begin{array}{c}\text { Serial } \\
\text { No }\end{array}$ & ACC. & $\begin{array}{c}\text { LMIH } \\
(\mu \mathrm{m})\end{array}$ & $\begin{array}{c}\text { WMIH } \\
(\mu \mathrm{m})\end{array}$ & $\begin{array}{l}\text { LST } \\
(\mu \mathrm{m}) \\
\end{array}$ & $\begin{array}{l}\text { WST } \\
(\mu \mathrm{m}) \\
\end{array}$ & $\begin{array}{l}\text { LLC } \\
(\mu \mathrm{m}) \\
\end{array}$ & $\begin{array}{l}\text { WLC } \\
(\mu \mathrm{m})\end{array}$ & $\begin{array}{c}\text { LSC } \\
(\mu \mathrm{m}) \\
\end{array}$ & $\begin{array}{l}\text { WSC } \\
(\mu \mathrm{m}) \\
\end{array}$ \\
\hline 1 & AG1 & $80.46 \pm 0.36^{d}$ & $3.54 \pm 0.06^{\mathrm{b}}$ & $36.11 \pm 0.03^{\mathrm{b}}$ & $24.65 \pm 0.02^{b}$ & $88.08 \pm 0.21^{c}$ & $23.82 \pm 0.01^{a}$ & $4.82 \pm 0.02^{c}$ & $5.81 \pm 0.01^{\mathrm{b}}$ \\
\hline 2 & AG2 & $93.79 \pm 0.26^{a}$ & $3.58 \pm 0.05^{\mathrm{b}}$ & $35.12 \pm 0.03^{c}$ & $24.74 \pm 0.01^{\mathrm{b}}$ & $89.54 \pm 0.23^{c}$ & $22.80 \pm 0.00^{\mathrm{b}}$ & $4.78 \pm 0.02^{c}$ & $5.56 \pm 0.02^{b}$ \\
\hline 3 & AG3 & $91.34 \pm 0.24^{\text {ab }}$ & $3.56 \pm 0.05^{\mathrm{b}}$ & $35.15 \pm 0.03^{c}$ & $24.81 \pm 0.01^{\mathrm{b}}$ & $88.09 \pm 0.26^{c}$ & $22.65 \pm 0.01^{\mathrm{b}}$ & $4.84 \pm 0.03^{c}$ & $5.82 \pm 0.02^{\mathrm{b}}$ \\
\hline 4 & AG4 & $90.46 \pm 0.53^{\text {ab }}$ & $3.50 \pm 0.05^{\mathrm{b}}$ & $34.16 \pm 0.03^{c}$ & $24.78 \pm 0.01^{\mathrm{b}}$ & $89.44 \pm 0.27^{c}$ & $21.83 \pm 0.01^{c}$ & $4.79 \pm 0.02^{c}$ & $5.81 \pm 0.01^{\mathrm{b}}$ \\
\hline 5 & AG5 & $89.33 \pm 0.56^{c}$ & $3.63 \pm 0.05^{b}$ & $33.11 \pm 0.03^{d}$ & $24.65 \pm 0.01^{b}$ & $89.91 \pm 0.26^{c}$ & $21.82 \pm 0.01^{c}$ & $4.80 \pm 0.02^{c}$ & $5.82 \pm 0.02^{b}$ \\
\hline 6 & AG6 & $91.51 \pm 0.19^{a b}$ & $3.51 \pm 0.02^{\mathrm{b}}$ & $33.10 \pm 0.03^{\mathrm{d}}$ & $24.80 \pm 0.01^{\mathrm{b}}$ & $88.04 \pm 0.27^{c}$ & $22.85 \pm 0.01^{\mathrm{b}}$ & $4.82 \pm 0.02^{c}$ & $5.80 \pm 0.01^{\mathrm{b}}$ \\
\hline 7 & AT1 & $64.40 \pm 0.60^{c}$ & $4.25 \pm 0.02^{\mathrm{a}}$ & $30.07 \pm 0.00^{f}$ & $22.11 \pm 0.00^{c}$ & $91.04 \pm 0.05^{b}$ & $19.53 \pm 0.01^{c}$ & $5.34 \pm 0.01^{\mathrm{b}}$ & $3.65 \pm 0.01$ \\
\hline 8 & AT2 & $63.34 \pm 0.67^{\mathrm{cf}}$ & $4.26 \pm 0.02^{a}$ & $31.26 \pm 0.00^{c}$ & $22.25 \pm 0.00^{c}$ & $92.03 \pm 0.05^{b}$ & $18.45 \pm 0.01^{f}$ & $5.29 \pm 0.01^{\mathrm{b}}$ & $3.89 \pm 0.01^{\circ}$ \\
\hline 9 & AT3 & $55.25 \pm 0.67^{\mathrm{cf}}$ & $4.25 \pm 0.02^{\mathrm{a}}$ & $31.12 \pm 0.00^{c}$ & $22.23 \pm 0.00^{c}$ & $91.35 \pm 0.05^{b}$ & $19.43 \pm 0.01^{\mathrm{c}}$ & $5.31 \pm 0.01^{\mathrm{b}}$ & $3.79 \pm 0.01$ \\
\hline 10 & AT 4 & $52.52 \pm 0.65^{\mathrm{cfg}}$ & $4.26 \pm 0.02^{a}$ & $31.16 \pm 0.00^{c}$ & $22.21 \pm 0.00^{c}$ & $92.54 \pm 0.05^{\mathrm{b}}$ & $18.85 \pm 0.01^{\mathrm{f}}$ & $5.29 \pm 0.01^{b}$ & $3.75 \pm 0.01$ \\
\hline 11 & AT5 & $51.43 \pm 0.57^{\mathrm{cfg}}$ & $4.24 \pm 0.02^{\mathrm{a}}$ & $31.17 \pm 0.00^{\mathrm{c}}$ & $22.21 \pm 0.00^{c}$ & $91.04 \pm 0.05^{b}$ & $19.83 \pm 0.02^{c}$ & $5.32 \pm 0.02^{\mathrm{b}}$ & $3.75 \pm 0.01^{\circ}$ \\
\hline 12 & AT6 & $51.51 \pm 0.65^{\mathrm{cfg}}$ & $4.20 \pm 0.02^{\mathrm{a}}$ & $31.15 \pm 0.00^{c}$ & $22.25 \pm 0.00^{c}$ & $92.01 \pm 0.05^{\mathrm{b}}$ & $19.85 \pm 0.01^{\mathrm{c}}$ & $5.32 \pm 0.02^{\mathrm{b}}$ & $3.81 \pm 0.06$ \\
\hline 13 & AT7 & $63.43 \pm 0.66^{\mathrm{cf}}$ & $4.26 \pm 0.02^{a}$ & $31.27 \pm 0.00^{c}$ & $22.30 \pm 0.00^{c}$ & $91.09 \pm 0.05^{\mathrm{b}}$ & $20.85 \pm 0.01^{\mathrm{d}}$ & $5.57 \pm 0.03^{b}$ & $3.78 \pm 0.01$ \\
\hline 14 & AT8 & $62.30 \pm 0.66^{c f}$ & $4.30 \pm 0.01^{\mathrm{a}}$ & $31.16 \pm 0.00^{\circ}$ & $22.29 \pm 0.00^{c}$ & $92.15 \pm 0.05^{\mathrm{b}}$ & $19.84 \pm 0.01^{\mathrm{c}}$ & $5.60 \pm 0.03^{b}$ & $3.76 \pm 0.01$ \\
\hline 15 & AT9 & $63.25 \pm 0.26^{6 f}$ & $4.26 \pm 0.02^{\mathrm{a}}$ & $31.26 \pm 0.00^{\circ}$ & $22.19 \pm 0.00^{c}$ & $92.05 \pm 0.05^{b}$ & $20.84 \pm 0.01^{\mathrm{d}}$ & $5.58 \pm 0.02^{\mathrm{b}}$ & $3.77 \pm 0.01^{\circ}$ \\
\hline 16 & AT10 & $80.43 \pm 0.30^{d}$ & $4.29 \pm 0.03^{\mathrm{a}}$ & $39.56 \pm 0.00^{\mathrm{a}}$ & $27.55 \pm 0.00^{2}$ & $95.44 \pm 0.04^{a}$ & $23.87 \pm 0.01^{a}$ & $6.61 \pm 0.03^{a}$ & $6.35 \pm 0.01^{*}$ \\
\hline
\end{tabular}

${ }^{*}$ Means with the same letter along columns are not significantly different at $\mathrm{P} \leq 0.05$

ACC. - Accessions, AG - Andropogon gayanus, AT - Andropogon tectorum No - Number, LMIH - Length of Microhairs, WMIH - Width of Microhairs, LST - Length of Stomata, WST - Width of Stomata, LLC - Length of Long Cells, WLC - Width of Long cells, LSC - Length of Short cell, WSC - Width of Short cells.

Table 4. Mean of some leaf epidermal characters on the abaxial surfaces of all accessions studied with Duncan multiple range test values

\begin{tabular}{|c|c|c|c|c|c|c|c|c|c|}
\hline 1 & AG1 & $65.98 \pm 0.88^{\mathrm{c}}$ & $3.67 \pm 0.04^{a}$ & $29.40 \pm 0.02^{b}$ & $33.25 \pm 0.03^{\mathrm{a}}$ & $83.59 \pm 0.30^{\mathrm{bc}}$ & $20.92 \pm 0.03^{\mathrm{b}}$ & $2.33 \pm 0.03^{a}$ & $1.28 \pm 0.02^{\mathrm{d}}$ \\
\hline 2 & AG2 & $65.69 \pm 0.82^{c}$ & $3.70 \pm 0.04^{a}$ & $29.45 \pm 0.03^{\mathrm{b}}$ & $33.19 \pm 0.03^{\mathrm{a}}$ & $83.61 \pm 0.31^{\mathrm{bc}}$ & $20.45 \pm 0.03^{\mathrm{b}}$ & $2.35 \pm 0.02^{\mathrm{a}}$ & $1.30 \pm 0.02^{\text {bed }}$ \\
\hline 3 & AG3 & $68.68 \pm 0.79^{\mathrm{bc}}$ & $3.66 \pm 0.03^{\mathrm{a}}$ & $29.65 \pm 0.03^{3 \mathrm{ab}}$ & $33.45 \pm 0.03^{\mathrm{a}}$ & $83.60 \pm 0.31^{\mathrm{bc}}$ & $20.62 \pm 0.03^{\mathrm{b}}$ & $2.04 \pm 0.03^{\text {ab }}$ & $1.29 \pm 0.02^{\mathrm{cd}}$ \\
\hline 4 & AG4 & $70.18 \pm 0.18^{a}$ & $3.67 \pm 0.04^{a}$ & $29.73 \pm 0.03^{3 \mathrm{ab}}$ & $33.15 \pm 0.03^{\mathrm{a}}$ & $83.61 \pm 0.28^{\mathrm{bc}}$ & $20.75 \pm 0.02^{\mathrm{b}}$ & $2.06 \pm 0.03^{\mathrm{ab}}$ & $1.27 \pm 0.02^{\mathrm{d}}$ \\
\hline 5 & AG5 & $70.54 \pm 0.18^{\mathrm{a}}$ & $3.67 \pm 0.04^{a}$ & $29.67 \pm 0.03^{3 \mathrm{bb}}$ & $33.04 \pm 0.03^{a}$ & $83.62 \pm 0.27^{\mathrm{bc}}$ & $20.35 \pm 0.02^{\mathrm{b}}$ & $2.08 \pm 0.03^{\mathrm{a}}$ & $1.30 \pm 0.02^{\text {cd }}$ \\
\hline 6 & AG6 & $65.63 \pm 0.66^{c}$ & $3.71 \pm 0.03^{\mathrm{a}}$ & $29.73 \pm 0.03^{3 \mathrm{ab}}$ & $33.65 \pm 0.03^{\mathrm{a}}$ & $83.98 \pm 0.27^{\mathrm{ab}}$ & $20.61 \pm 0.02^{\mathrm{b}}$ & $2.45 \pm 0.02^{a}$ & $1.30 \pm 0.02^{\text {bed }}$ \\
\hline 7 & AT1 & $53.45 \pm 0.09^{c}$ & $3.40 \pm 0.05^{\mathrm{bc}}$ & $29.89 \pm 0.05^{\mathrm{ab}}$ & $23.28 \pm 0.02^{c}$ & $81.05 \pm 0.05^{\text {sb }}$ & $17.15 \pm 0.02^{\mathrm{d}}$ & $1.63 \pm 0.02^{\mathrm{bc}}$ & $1.48 \pm 0.04^{\text {bed }}$ \\
\hline 8 & AT2 & $55.84 \pm 0.08^{\mathrm{c}}$ & $3.65 \pm 0.04^{\mathrm{a}}$ & $29.81 \pm 0.06^{\mathrm{ab}}$ & $24.19 \pm 0.02^{\mathrm{c}}$ & $80.07 \pm 0.05^{c}$ & $17.23 \pm 0.05^{\mathrm{d}}$ & $1.62 \pm 0.03^{\mathrm{c}}$ & $1.55 \pm 0.04^{a}$ \\
\hline 9 & AT3 & $54.37 \pm 0.09^{c}$ & $3.54 \pm 0.04^{\mathrm{ab}}$ & $29.76 \pm 0.04^{\mathrm{ab}}$ & $24.28 \pm 0.02^{c}$ & $81.05 \pm 0.05^{c}$ & $17.39 \pm 0.05^{\mathrm{d}}$ & $1.57 \pm 0.03^{c}$ & $1.45 \pm 0.05^{\text {abcd }}$ \\
\hline 10 & AT4 & $56.95 \pm 0.07^{\mathrm{c}}$ & $3.50 \pm 0.04^{\mathrm{ab}}$ & $29.87 \pm 0.04^{\mathrm{ab}}$ & $23.48 \pm 0.02^{c}$ & $81.09 \pm 0.06^{\mathrm{c}}$ & $18.42 \pm 0.02^{\mathrm{c}}$ & $1.59 \pm 0.02^{\mathrm{c}}$ & $1.42 \pm 0.05^{\mathrm{abcd}}$ \\
\hline 11 & AT5 & $53.94 \pm 0.08^{c}$ & $3.48 \pm 0.05^{\text {abc }}$ & $29.58 \pm 0.05^{\mathrm{b}}$ & $23.35 \pm 0.02^{c}$ & $81.05 \pm 0.06^{c}$ & $18.25 \pm 0.02^{c}$ & $1.60 \pm 0.03^{c}$ & $1.45 \pm 0.04^{\mathrm{abcd}}$ \\
\hline 12 & AT6 & $54.95 \pm 0.08^{c}$ & $3.49 \pm 0.05^{\mathrm{abc}}$ & $29.79 \pm 0.04^{\mathrm{ab}}$ & $23.25 \pm 0.02^{c}$ & $81.03 \pm 0.08^{c}$ & $18.19 \pm 0.02^{c}$ & $1.60 \pm 0.03^{c}$ & $1.46 \pm 0.05^{\text {abcd }}$ \\
\hline 13 & AT7 & $61.80 \pm 0.10^{\mathrm{d}}$ & $3.48 \pm 0.09^{\mathrm{bl} c}$ & $29.75 \pm 0.05^{\mathrm{ab}}$ & $24.32 \pm 0.02^{\mathrm{c}}$ & $81.07 \pm 0.06^{c}$ & $17.44 \pm 0.03^{\mathrm{d}}$ & $1.62 \pm 0.02^{c}$ & $1.44 \pm 0.05^{\mathrm{abcd}}$ \\
\hline 14 & AT8 & $62.75 \pm 0.09^{d}$ & $3.53 \pm 0.06^{\mathrm{ab}}$ & $29.78 \pm 0.06^{\mathrm{ab}}$ & $23.27 \pm 0.02^{c}$ & $81.05 \pm 0.07^{c}$ & $18.55 \pm 0.02^{c}$ & $1.59 \pm 0.03^{c}$ & $1.49 \pm 0.04^{\text {alc }}$ \\
\hline 15 & AT9 & $61.72 \pm 0.08^{d}$ & $3.47 \pm 0.06^{\text {blc }}$ & $29.83 \pm 0.05^{\mathrm{ab}}$ & $24.31 \pm 0.02^{c}$ & $81.04 \pm 0.05^{c}$ & $18.23 \pm 0.02^{c}$ & $1.63 \pm 0.02^{c}$ & $1.47 \pm 0.05^{\text {alc }}$ \\
\hline 16 & AT10 & $68.80 \pm 0.09^{\mathrm{bc}}$ & $3.49 \pm 0.06^{\mathrm{abc}}$ & $31.73 \pm 0.05^{\mathrm{a}}$ & $30.35 \pm 0.02^{b}$ & $88.09 \pm 0.05^{\mathrm{a}}$ & $22.46 \pm 0.02^{\mathrm{a}}$ & $1.60 \pm 0.03^{c}$ & $1.50 \pm 0.05^{\text {abc }}$ \\
\hline
\end{tabular}

${ }^{*}$ Means with the same letter along columns are not significantly different at $\mathrm{P} \leq 0.05$

ACC-Accession, AG - Andropogon gayanus, AT - Andropogon tectorum No - Number, LMIH - Length of Microhairs, WMIH - Width of Microhairs, LST - Length of Stomata, WST - Width of Stomata, LLC - Length of Long Cells, WLC - Width of Long cells, LSC - Length of Short cell, WSC- Width of Short cell

\section{Discussion}

Anatomically, the two species of Andropogon studied showed remarkable differences and similarities among them. The importance of leaf epidermis study in grass systematics was first documented by Krause (1909, 1910, 1912 and 1913; cited by Srivastava, 1978). Avdulov (1931), Prat (1932, 1960), Carquist (1961) and Illoh (1995) and stated that the leaf provides a variety of anatomical features that can be of taxonomic importance and later emphasized the vital role of foliar epidermal studies in their different reports. Since then, 
leaf anatomy and especially the epidermis have been used with other characters like chromosome studies, whole plant morphology, reproductive biology, etc., as an aid to grass systematics. Metcalfe (1954) noted that certain epidermal characters such as shape of the subsidiary stomata cells, microhairs, trichomes and prickles are significantly different.

In this study, the costal zones of both adaxial and abaxial surfaces of all accessions studied showed similar features with little or no variation in their expression. On the intercostal zones however, there are variations in the distribution of the features between the abaxial and adaxial surfaces of the accessions studied. However, some of the characters were present in all of them and may be typical of the genus or family.

Islam et al. (2009) reported in their study of epidermal features on rice leaves that the leaves' surfaces consist of several types of cells and appendages, e.g., long and short cells, stomata with guard cells, prickle hairs, papillae, etc.

In this study, the long epidermal cells show variations in the accessions. The epidermal cells are mostly rectangular with wavy walls. This supports the findings of Folorunso and Olaniyan (2009) where they reported the type of epidermal cells in Andropogon species to be rectangular cells with wavy walls. The short cells are mostly solitary in the two species, with rare cases of paired short cells. Of all the epidermal characters studied, the length and width of long cells, short cells, micro hair and anticlinal walls showed significant differences between the species complex. The long cells and short cells are longer in A. tectorum than in A. gayanus. Kiwani, has the longest long cells, short cells and stomata on the adaxial surface but varies on the abaxial surface. Microhair are longer in A. gayanus than in A. tectorum.

All these more conspicuous features in $A$. gayanus combined with its straight and slightly wavy anticlinal walls may be adaptive and endemic in the savanna species. Characters typical of the genus are the largely thick cell wall, paracytic stomata type; largely numerous papillae which are also uniform in size. All these characters are of taxonomic importance in the identification and classification of the genus. The hairiness observed in $A$. gayanus is largely due to the presence of microhairs found on certain vegetative and floral parts. The microhair was sparse in some accessions and comparatively frequent in others, one of the major taxonomic values in delimiting the two species studied. Presence of Glandular trichomes in both diploid and tetraploid of Andropogon tectorum is a diagnostic feature for the species as none of such was seen in A. gayanus.

Faluyi and Nwokeocha's (1993) finding showed the taxonomic value of microhairs, prickle hairs and short cells in the genus Oryza. The results of their work showed that distribution of prickle hair and short cells in intercostal zones, and the ratio of length of apical: basal cells of the microhair carried taxonomic values as these were used to delimit the two ploidy levels of Oryza punctata.

Papillae are protrusions of various shapes and sizes from the outer walls of the epidermis (Islam et al., 2009). Small and medium-sized circular papillae are present on the costal zones of the two species studied. Nwokeocha (1996) also reported the presence of papillae on both abaxial and adaxial surfaces of Oryza sativa and Oryza punctata leaves.

The size and shape of stomata are important taxonomically (Thair and Rajput, 2009). The role of stomata is closely associated with various physiological processes on which the success of each species depends. Paracytic stomata (guard cells surrounded by two subsidiary cells) are present in the two species studied. Rubina et al. (2007) also reported the occurrence of paracytic stomata on both abaxial and adaxial surfaces of monocots. The subsidiary cells are mostly triangular in shape but often dome-shaped too. The interstomatal cells are rectangular in all. Islam et al. (2009) also made this observation on the leaves of rice. AT10, Kiwani, is unique in having the highest number of bands of stomata, the stomata are big. This is consistent with gigas effect occasioned by polyploid. Bigger stomata do not necessarily constitute a disadvantage in evapotranspiration like density would do. Therefore, the polyploid in A. tectorum will not suffer the disadvantage that Adedeji and Faluyi (2006) attributed to Panicum maximum.

Prickle hairs have been used as diagnostic feature by scientists such as Islam et al. (2009) on their work on the epidermal features of leaves of rice. Adedeji and Faluyi (2006) reported the presence and absence of prickle hair in their work on some accessions of Panicum maximum in Southwestern, Nigeria; Nwokeocha 
(1996) also reported the occurrence of prickle hairs in her study on the foliar epidermal studies in Oryza punctata. Prickle hair is present in both surfaces of all the species but at different frequencies. The prickle hairs on the leaf margin and edge are distributed more or less equidistantly in the work of Islam et al. (2009) on the leaves of rice. This is in agreement with this study as the prickle hairs at the edge and margin are often distributed at equal distance to each other which could be the diagnostic features of the family Poaceae. Observations in this study disagrees with Folorunsho and Olaniyan (2009) with respect to absence of prickle hairs and the complete absence of the characteristic base of the microhairs in A.gayanus, cluster of cells forming a dome (cluster of cells that provide a bigger platform for the microhairs to sit).

\section{Conclusions}

In conclusion, characters like the presence of cluster of cells at the base of microhairs of $A$. gayanus and the occurrence of bigger stomata in Kiwani, provides additional criteria in delimitation of the species. The proof that Kiwani is not $A$. gayanus is based essentially on the structure of the microhair in $A$. gayanus a characteristic many-celled inflated base which is absent in Kiwani.

\section{Authors' Contributions}

Conceptualization: FMO, CCN, JOF. Collection of preliminary data; Collection of samples during survey; Methodology; Investigation: FMO; funding acquisition; Resources; Writing-review and editing: CCN. Supply of modified method for peeling epidermal preparation; Reviewing and editing: FMO. Writing-original draft: Supervision; JOF.

All authors read and approved the final manuscript

\section{Acknowledgements}

The work was supported by Bill Dahl Graduate Student Research Grant Award (2019), Botanical Society of America, United States of America and Academic Staff Union of Universities (ASUU) Scholarship Award for 2019/2020 Academic Session.

\section{Conflict of Interests}

The authors declare that there are no conflicts of interest related to this article.

\section{References}

Adedeji O, Faluyi JO (2006). Morphological, agrobotanical and reproductive studies in 35 accessions of Panicum maximum Jacq. in South Western Nigeria. Research Journal of Botany 1(2):67-74. https://doi.org/10.3923/rjb.2006.64.74

Avdulov NP (1931). Karyo-systematiche Untersuchung der Familie Gramineen. Bulletin of Applied Genetics and Plant Breeding 44:1-428.

Bogdan AV (1977). Pasture and Fodder Plants (Grasses and Legumes). Longman Press, New York, USA, pp 1-39, 229231. 
Bowden BN (1963). Studies on Andropogon gayanus Kunth. I. The use of Andropogon gayanus in agriculture. Empire Journal of Experimental Agriculture 31:267-273.

Carlquist S (1961). Comparative plant anatomy. Holt, Rinchart and Wintson, New York, pp 29-36.

Chlleda HR, Crowder LV (1982). Tropical Grassland Husbandry. First edition, Longman, London, pp 346-367.

Clayton WD (1969). Flora of West Tropical Africa. In: Hutchinson J, Dalziel JM (Eds). Vol. 111(2), $2^{\text {nd }}$ ed. (Revised by F. N. Hepper). Crown Agents for Overseas Governments and Administration, London.

Cutler DF (1978). Applied Plant Anatomy. (1 $1^{\text {st }}$ ed.) Longman Inc. New York, pp 5-6.

Faluyi JO, Nwokeocha CC (1993). Occurrence and distribution of ploidy level of Oryza punctata Katschy ex Steud. in Africa. Feddes Repertorium 104(3-4):215-226. https://doi.org/10.1002/fedr.19931040309

Folorunso AE, Olaniyan OJ (2009). Comparative foliar epidermal studies in Andropogon gayanus (Kunth) and Andropogon tectorum (Schum \& Thonns) in Nigeria. Thaiszia Journal of Botany Kosice 19:27-35.

Hattersley PW (1984). Characterization of C4 type leaf anatomy in grasses (Poaceae). Mesophyll: bundle sheath area ratios. Annals of Botany 53:163-179. https://doi.org/10.1093/oxfordjournals.aob.a086678

Hutchinson J, Dalziel JM (1972). Floral of West Tropical Africa. Vol. III Part 2. - Crown Agents, London, pp $459-461$.

Illoh HC (1995). Foliar epidermis and petiole anatomy of four species of Celosia L. Nigeria. Feddes Repertorium 106(12):15-23. https://doi.org/10.1002/fedr.19951060107

Islam MT, Sarwar AG, Begum HH, Ito T (2009). Epidermal features of rice leaf CV. BRRI Dhan29. Bangladesh Journal of Plant Taxonomy 16(2):177-180. https://doi.org/10.3329/bjpt.v16i2.3931

Krause EHL (1909). Ein Basserungen am system der Gramineen. Beihefte Botanischen Zentralbl 29:127-146.

Krause EHL (1910). Weitere Basserungen am system der Gramineen. Beiheft Botanischen Zentralbl 27:412-424.

Krause EHL (1912). Beitrage Zur Gramineen systematic. Beihefte Botanischen Zentralbl 29:127-146.

Krause EHL (1913). Beitrage Zur Gramineen systematic. Beihefte Botanischen Zentralbl 30:111-123.

Lowe J (1989). The Floral of Nigerian Grasses. $2^{\text {nd }}$ ed. Ibadan University Press, pp 214.

Metcalfe CR (1954). Recent work on the systematic anatomy of the monocotyledon (with special reference to investigation of the Jodrell Lab at Kew). Kew Bulletin 9(4):523-532.

Metcalfe CR, Chalk L (1950). Anatomy of the Dicotyledons. Vol.1. - Clarendon Press, Oxford, pp 806.

Metcalfe CR (1960). Anatomy of Monocotyledons. Vol. 1. Gramineae. Oxford University Press, Oxford, pp 61-66, $167-$ 170.

Nwokeocha CC (1996). Foliar epidermal studies of Oryza punctata. Nigeria Journal of Botany 9:49-58.

Ogundipe OT, Olatunji OA (1989). The vegetative anatomy of the Nigerian species of Echinochloa P. Beauv. - Nigeria Journal of Botany 1:37-48.

Ogundipe OT, Olatunji OA (1991). Vegetative anatomy of Brachiaria obtussiflora (Hochst. Ex A. Rich) Stapf and Brachiaria callopus (Pilg.) Stapf (Poaceae). Feddes Repertorium 102(3-4):159-166. https://doi.org/10.1002/fedr.19911020302

Okoli BE, Olorode O (1983). Cytogenetic studies in the Andropogon gayanus- A. tectorum Complex (Gramineae). Botany Journal of Linnean Society 87:263-271. https://doi.org/10.1111/j.1095-8339.1983.tb00994.x

Olorode O (1984). Taxonomy of West African Flowering Plants. (Revised edn.) Longman Group Limited Publishers, London, pp 123-127.

Pagot J (1993). Animal Production in the Tropics. $1^{\text {st }}$ edition, Macmillan Press, London, pp 163-181, 224-225.

Palmer PG, Gerbeth-Jones S (1988). A scanning electron microscope survey of the epidermis of East African grasses, V, and West African supplement. Smithsonian Contribution to Botany 62:1-120 https://doi.org/10.5479/si.0081024X.67

Prat H (1932). L'epiderme des Graminees, etude anatomique et systematique. Annals of Science and Natural Botany 14:117-324.

Prat H (1960). Ver une classification naturelle de Graminees. Bulletin of Society of Botany 107:32-79.

Renvoize SA (1982). A survey of leaf blade anatomy in grasses I. Andropogoneae. Kew Bulletin 37(2):315-321.

Renvoize SA (1987). A survey of leaf blade anatomy in grasses XI. Paniceae. Kew Bulletin 42(3):739-768.

Rubina A, Sharmeen S, Anjum P (2007). Stomata types of monocots within flora of Karachi, Pakistan. Pakistan Journal of Botany 39(1):15-21.

Srivastava AK (1978). Study of leaf epidermis in the genus Digitaria Rich (Gramineae). Journal of India Botanical Society 37:155-160.

Stace CA (1965). Cuticular studies as an aid to plant taxonomy. Bulletin of the British Museum (National History) of Botany 4:3-78. 
Stace CA (1984). The taxonomic importance of the leaf surface. In: VH Herwood, DM Moore (Eds). Current Concepts in Plant Taxonomy Systematic Association. Spec. Academic Press, London and Orlando, 25:67-94.

Stanfield DP (1970). The Floral of Nigeria Grasses. ( ${ }^{\text {st }}$ ed.) University of Ibadan Press, Ibadan, pp 83.

Tateoka T, Inoue S, Kwano S (1959). Notes on some grasses. IX: Systematic Significances of bicellular microhair of leaf epidermis. Botanical Gazette 121:80-91. https://doi.org/10.1086/336048

Thair SS, Rajput MTM (2009). S.E.M. structure, distribution and taxonomic significance of foliar stomata in Sibbaldia L., species (Rosaceae). Pakistan Journal of Botany 41(5):2137-2143.
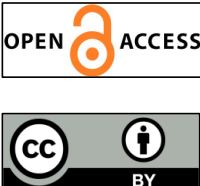

The journal offers free, immediate, and unrestricted access to peer-reviewed research and scholarly work. Users are allowed to read, download, copy, distribute, print, search, or link to the full texts of the articles, or use them for any other lawful purpose, without asking prior permission from the publisher or the author.

License - Articles published in Notulae Scientia Biologicae are Open-Access, distributed under the terms and conditions of the Creative Commons Attribution (CC BY 4.0) License.

(c) Articles by the authors; SHST, Cluj-Napoca, Romania. The journal allows the author(s) to hold the copyright/to retain publishing rights without restriction. 